Eur. J. Mineral.

2019, 31, 183-192

Published online 12 September 2018

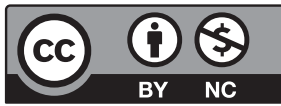

\title{
Nomenclature and classification of the spinel supergroup
}

\author{
Ferdinando BOSI ${ }^{1, *}$, CRISTIAN BIAGIONI ${ }^{2}$ and Marco PASERO ${ }^{2}$ \\ ${ }^{1}$ Department of Earth Sciences, Sapienza University of Rome, P. Aldo Moro 5, 00185 Roma, Italy \\ *Corresponding author, e-mail: ferdinando.bosi@uniroma1.it \\ ${ }^{2}$ Dipartimento di Scienze della Terra, Università di Pisa, Via S. Maria 53, 56126 Pisa, Italy
}

\begin{abstract}
A new, IMA-approved classification scheme for the spinel-supergroup minerals is here reported. To belong to the spinel supergroup, a mineral must meet two criteria: (i) the ratio of cation to anion sites must be equal to 3:4, typically represented by the general formula $\mathrm{AB}_{2} \mathrm{X}_{4}$ where $\mathrm{A}$ and $\mathrm{B}$ represent cations (including vacancy) and $\mathrm{X}$ represents anions; (ii) its structure must comprise a heteropolyhedral framework of four-fold coordination polyhedra $\left(T \mathrm{X}_{4}\right)$ isolated from each other and sharing corners with the neighboring six-fold coordination polyhedra $\left(M \mathrm{X}_{6}\right)$, which, in turn, share six of their twelve $\mathrm{X}$-X edges with nearestneighbor $M \mathrm{X}_{6}$. Regardless of space group, the $\mathrm{X}$ anions form a cubic close-packing and each $\mathrm{X}$ anion is bonded to three $M$-cations and one $T$-cation. The fifty-six minerals of the spinel supergroup are divided into three groups on the basis of dominant $\mathrm{X}$ anion: $\mathrm{O}^{2-}$ (oxyspinel), $\mathrm{S}^{2-}$ (thiospinel), and $\mathrm{Se}^{2-}$ (selenospinel). Each group is composed of subgroups identified according to the dominant valence and then the dominant constituent (or heterovalent pair of constituents) represented by the letter $\mathrm{B}_{\text {in }}$ the formula $\mathrm{AB}_{2} \mathrm{X}_{4}$. The oxyspinel group (33 species) can be divided into the spinel subgroup 2-3 $\left(\mathrm{A}^{2+} \mathrm{B}_{2}^{3+} \mathrm{O}_{4}\right)$ and the ulvöspinel subgroup 4-2 $\left(\mathrm{A}^{4+} \mathrm{B}_{2}^{2+} \mathrm{O}_{4}\right)$, the thiospinel group (20 species) into the carrollite subgroup 1-3.5 $\left(\mathrm{A}^{1+} \mathrm{B}_{2}^{3.5+} \mathrm{S}_{4}\right)$ and the linnaeite subgroup 2-3 $\left(\mathrm{A}^{2+} \mathrm{B}_{2}^{3+} \mathrm{S}_{4}\right)$, finally, the selenospinel group (3 species) into the bornhardtite subgroup $2-3\left(\mathrm{~A}^{2+} \mathrm{B}^{3+}{ }_{2} \mathrm{Se}_{4}\right)$ and the potential "tyrrellite subgroup" ( $\left(\mathrm{A}^{1+} \mathrm{B}_{2}^{3.5+} \mathrm{S}_{4}\right.$, currently composed by only one species). Once the subgroup is established based on the valence of $\mathrm{B}$, then the mineral species is identified by the combination of the dominant A- and B-cations. Moreover, the present nomenclature redefines the ideal formulae of titanomaghemite, cuprorhodsite, malanite, maghemite, filipstadite, tegengrenite, rhodostannite, toyohaite and xingzhongite as well as discredits "iwakiite", "hydrohetaerolite" and "ferrorhodsite".
\end{abstract}

Key-words: spinel; oxyspinel; thiospinel; selenospinel; nomenclature; classification.

\section{Introduction}

The central role of spinel-type compounds, both in the Earth Sciences and in many other scientific and technological fields, is well known. Indeed, minerals with the spinel structure crystallize in a wide range of physical-chemical conditions, from the upper mantle to crust, as well as in extraterrestrial bodies, e.g., Moon, Mars, and meteorites (e.g., Papike et al., 2005; Righter et al., 2006). Compounds with spinel-type structures also play a prominent role in solid-state materials science because of their physical properties.

As pointed out by Biagioni \& Pasero (2014), there is a wide chemical variability of the spinel minerals. Thus, the development of a comprehensive classification system is a necessary step to understand the processes that govern their diversity. The present recommended nomenclature and classification was approved by the Commission on New Minerals, Nomenclature and Classification (CNMNC) of the International Mineralogical Association (IMA), voting proposal $17-\mathrm{H}$.

\section{Spinel basic aspects}

\subsection{Structure}

The spinel-type structure is adopted by many compounds with a cations-to-anions ratio of 3:4, typically represented by the general formula $\mathrm{AB}_{2} \mathrm{X}_{4}$ where the letters (not italicized) $\mathrm{A}$ and $\mathrm{B}$ indicate constituents (not crystallographic sites) represented by a large number of different cations or vacancy and $\mathrm{X}$ represents anions, such as $\mathrm{O}^{2-}, \mathrm{S}^{2-}, \mathrm{Se}^{2-}$, $\mathrm{N}^{3-}, \mathrm{Te}^{2-} \mathrm{Cl}^{1-},(\mathrm{CN})^{1-}$ and $\mathrm{F}^{-}$. The basic structure may be described as a slightly distorted cubic close-packed array of $\mathrm{X}$-anions with A- and B-cations occupying $1 / 8$ of the tetrahedrally and $1 / 2$ of the octahedrally coordinated sites (respectively, $T$ and $M$, letters italicized). The structures of mineral species belonging to the spinel supergroup can be more conveniently described in terms of a heteropolyhedral framework that possesses some basic features: it is formed by $T \mathrm{X}_{4}$ tetrahedra isolated from each other and sharing corners with the neighboring $M \mathrm{X}_{6}$ octahedra; the $M \mathrm{X}_{6}$ octahedron shares six of its twelve $\mathrm{X}-\mathrm{X}$ edges with nearest-neighbor $M \mathrm{X}_{6}$ 


\section{(a)}

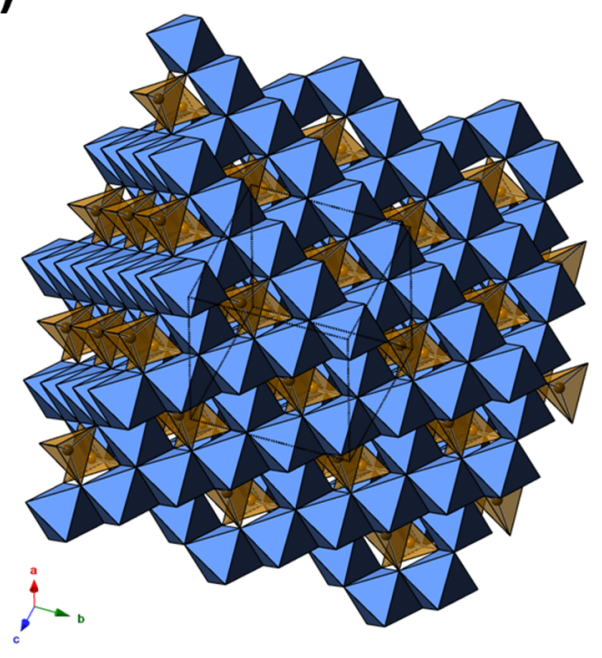

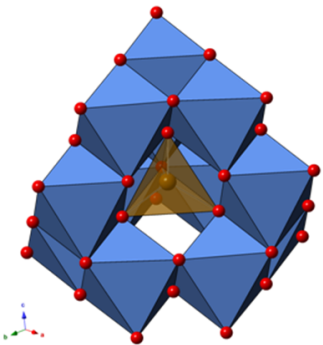

(b)

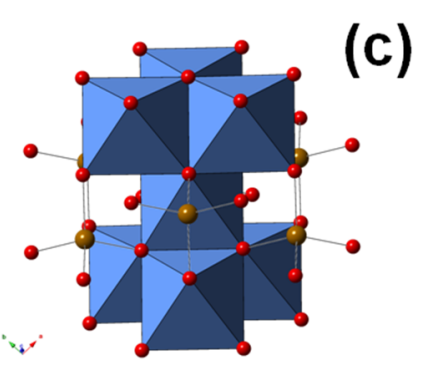

Fig. 1. Crystal structure of spinel (a); details of the local bonding environment around the $T$ site (b) and the $M$ sites (c). Brown $=T \mathrm{X}_{4}$ polyhedron; light blue $=M \mathrm{X}_{6}$ polyhedron; red $=\mathrm{X}$ anion. The $\mathrm{X}$ anions are not shown in (a), and $T \mathrm{X}_{4}$ is shown as ball-and-stick in (c).

octahedra. The $\mathrm{X}$ anion is in turn four-fold coordinated by three $M$ cations and one $T$ cation (Fig. 1). This polyhedral arrangement is consistent with several space groups ranging from the high-symmetry space-group type $F d \overline{3} m$ of cubic aristotype spinel (Bragg, 1915; Nishikawa, 1915) to $P 4_{1} 32$, $P 4_{1} 2{ }_{1} 2, I 4_{1} / a m d, I 4_{1} / a, P \overline{4} m 2$ and $R 3$.

On the other hand, there are minerals with general formula $\mathrm{AB}_{2} \mathrm{O}_{4}$ but with a structure quite distinct from that of spinel, which therefore do not belong to the spinel supergroup. For example, the orthorhombic structure of xieite $\left(\mathrm{FeCr}_{2} \mathrm{O}_{4}\right.$, the high-pressure polymorph of chromite) comprises eight-fold coordinated $\mathrm{Fe}^{2+} ;$ in wadsleyite $\left(\beta-\mathrm{Mg}_{2} \mathrm{SiO}_{4}\right)$, tetrahedra share a corner to form the $\mathrm{Si}_{2} \mathrm{O}_{7}$ group; the structure of chrysoberyl $\left(\mathrm{BeAl}_{2} \mathrm{O}_{4}\right)$ and forsterite $\left(\alpha-\mathrm{Mg}_{2} \mathrm{SiO}_{4}\right)$ is based on a hexagonal close-packed array of oxygen atoms, in which tetrahedra shares three edges with neighboring octahedra.

\subsection{Cation distributions}

Traditionally spinels are denoted as either "normal spinels", where for example the $T$ sites are occupied by divalent cations and the $M$ sites are occupied by trivalent cations, or "inverse spinels" whose $T$ sites are occupied by trivalent cations and the $M$ sites by one divalent plus one trivalent cation. Given the structural formula ${ }^{T}\left(\mathrm{~A}_{1-i} \mathrm{~B}_{i}\right)^{M}\left(\mathrm{~A}_{i} \mathrm{~B}_{2-i}\right) \mathrm{X}_{4}$, the two extreme distributions correspond to $i=0$ (normal) and $i=1$ (inverse). The value of $i$, the inversion parameter, depends on several factors, e.g., temperature, oxygen fugacity, crystallization kinetics, covalency effects (such as $s p^{3}$ hybridization) and stabilization energies of cations at the $M$ site (e.g., O’Neill \& Navrotsky, 1984; Nell et al., 1989; O’Neill et al., 1992; Della Giusta et al., 1996; Redfern et al., 1999; Andreozzi et al., 2000; Andreozzi \& Princivalle, 2002; Lucchesi et al., 2010; Papike et al., 2015; Bosi \& Andreozzi, 2017).
Consequently, spinels can display extensive cation disorder over the $T$ and $M$ sites; an accurate determination of site partitioning would require the combination of data obtained by different methods, such as single-crystal X-ray diffraction (SC-XRD) and electron microprobe analysis (EMPA), possibly integrated with additional spectroscopic information (e.g., Mössbauer and optical absorption spectroscopy). Hatert \& Burke (2008) noted the problem of uncertainty in the spinel cation distributions for nomenclature purposes, and suggested to keep the A and B constituents separate, regardless of their site occupancies as these are not imposed by valency considerations. Hence, the present classification is based on chemical formulae as resulting from chemical information only.

\subsection{Chemical variability}

The spinel structure is remarkably flexible in a chemical sense, accommodating atoms of a wide range of size and charge, as well as vacancies. Extensive substitution series occur among various spinel end-members, particularly among pairs with the same ordering type. For example, magnesiochromite-chromite $\mathrm{MgCr}_{2} \mathrm{O}_{4}-\mathrm{FeCr}_{2} \mathrm{O}_{4}$ is a binary system consisting of two normal spinels (Lenaz et al., 2004), whereas qandilite-ulvöspinel $\mathrm{TiMg}_{2} \mathrm{O}_{4}-\mathrm{TiFe}_{2} \mathrm{O}_{4}$ is a binary system consisting of two inverse spinels (Bosi et al., 2014).

The chemical variability is not limited only to cations, but encompasses anions, too. Most naturally occurring spinels are oxides, but there are also rare sulfide and selenide spinel-type minerals. If one considers synthetic compounds, this structural family also includes halides, pseudohalides (cyanides), tellurides and nitrides. There are many studies focusing on the synthesis and characterization of spinel compositions, and several of them have produced compositions that are not presently known to occur in 
nature: e.g., $\mathrm{MgMn}_{2} \mathrm{O}_{4}$ (Radhakrishnan \& Biswas, 1975), $\mathrm{ZnAl}_{2} \mathrm{~S}_{4}$ (Steigmann, 1967), $\mathrm{ZnCr}_{2} \mathrm{Se}_{4}$ (Von Philipsborn, 1971), $\mathrm{NiLi}_{2} \mathrm{~F}_{4}$ (Müller, 2007), $\mathrm{ZnLi}_{2} \mathrm{Cl}_{4}$ (Sassmannshausen et al., 1996), $\mathrm{ZnK}_{2}(\mathrm{CN})_{4}$ (Rohrer, 2001), $\mathrm{Cr}^{2+} \mathrm{Cr}_{2} \mathrm{Te}_{4}^{2-}$ (ICSD No. 43041) and $\mathrm{SiTi}_{2} \mathrm{~N}_{4}$ (Ching et al., 2001). Spinels with $\mathrm{X}=\mathrm{F}^{1-}, \mathrm{Cl}^{1-},(\mathrm{CN})^{1-}, \mathrm{Te}^{2-}$, and $\mathrm{N}^{3-}$ are only known as synthetic phases, whereas spinels with $\mathrm{X}=\mathrm{O}^{2-}, \mathrm{S}^{2-}$ and $\mathrm{Se}^{2-}$ occur in nature. In contrast to the extended substitution series occurring among end-members comprising the same anion, but different cations, there are miscibility gaps among the oxy-, thio- and seleno-species in natural samples.

\section{The supergroup-group-subgroup hierarchy of the spinels}

In line with the CNMNC guidelines (Mills et al., 2009), the 56 valid species of the spinel supergroup are divided here into three groups on the basis of the dominant $\mathrm{X}$ species (O, S, Se; see Table 1):

(1) Oxyspinel group;

(2) Thiospinel group;

(3) Selenospinel group.

Within each group, subdivision into subgroups is performed according to the cation charge arrangement combinations, constrained by the $(\mathrm{A}+\mathrm{B})$ to $\mathrm{X}$ atomic ratio of 3:4 (see above). Various distinct combinations may occur in the spinel supergroup, although some of them have been observed only in synthetic compounds. A useful way to group the cation charge arrangements is based on the weighted average of the sum of formal charges of the constituents $\mathrm{A}$ and B; for example:

- 1-3.5, $(\mathrm{A})^{\Sigma 1+}\left(\mathrm{B}_{2}\right)^{\Sigma 7+}$ as in ${ }^{\mathrm{A}}\left(\mathrm{Cu}^{+}\right)^{\mathrm{B}}\left(\mathrm{Cr}_{1.5}^{3+} \mathrm{Sb}_{0.5}^{5+}\right) \mathrm{S}_{4}$ (florensovite);

- 2-3, $(\mathrm{A})^{\Sigma 2+}\left(\mathrm{B}_{2}\right)^{\Sigma 6+}$ as in ${ }^{\mathrm{A}}\left(\mathrm{Mg}^{2+}\right)^{\mathrm{B}}\left(\mathrm{Al}^{3+}\right)_{2} \mathrm{O}_{4}$ (spinel);

- 4-2, $(\mathrm{A})^{\Sigma 4+}\left(\mathrm{B}_{2}\right)^{\Sigma 4+}$ as in ${ }^{\mathrm{A}}\left(\mathrm{Ti}^{4+}\right)^{\mathrm{B}}\left(\mathrm{Fe}_{2}^{2+}\right) \mathrm{O}_{4}$ (ulvöspinel).

Note that the constituent $\mathrm{B}$ (and sometimes also A) can represent a heterovalent pair of ions imposed by the electroneutrality principle in the end-member compositions.

In accord with the above-mentioned cation charge arrangements, the oxyspinel group can be divided into subgroups 2-3 and 4-2. In the thiospinel and selenospinel groups, some uncertainties in the ion oxidation states (e.g., Vaughan \& Craig, 1978; Barkov et al., 2000; Pattrick et al., 2008) make the classification more difficult and, likely, the assignment of formal charges in such compounds has very little meaning (e.g., Goodenough, 1969). However, on the basis of the current knowledge, they can be theoretically divided as follows: thiospinel-subgroups 1-3.5 and 2-3; selenospinel-subgroups 1-3.5 and 2-3 (Fig. 2). This subdivision scheme can easily be extended, for example, to possible subgroups $2-1$ and 6-1. Moreover, new groups can be established if $\mathrm{AB}_{2} \mathrm{X}_{4}$ compounds with spinel structures are discovered as new minerals.

\section{Spinel classification by chemical formula}

In order to assist the geoscience community in identifying spinel species, and to simplify the nomenclature (Hatert \& Burke, 2008), cations at the $T$ and $M$ sites are grouped
Table 1. A classification of the 56 species in the spinel supergroup.

\begin{tabular}{|c|c|c|c|}
\hline \multicolumn{4}{|c|}{ Oxyspinel group } \\
\hline Spinel subgroup (2-3) & $A^{2+}$ & $\mathbf{B}^{3+}$ & $\mathbf{X}$ \\
\hline Chromite & $\mathrm{Fe}$ & $\mathrm{Cr}_{2}$ & $\mathrm{O}_{4}$ \\
\hline Cochromite & Co & $\mathrm{Cr}_{2}$ & $\mathrm{O}_{4}$ \\
\hline Coulsonite & $\mathrm{Fe}$ & $\mathrm{V}_{2}$ & $\mathrm{O}_{4}$ \\
\hline Cuprospinel & $\mathrm{Cu}$ & $\mathrm{Fe}_{2}$ & $\mathrm{O}_{4}$ \\
\hline Dellagiustaite & V & $\mathrm{Al}_{2}$ & $\mathrm{O}_{4}$ \\
\hline Deltalumite & $\left(\mathrm{Al}_{0.67} \square_{0.33}\right)$ & $\mathrm{Al}_{2}$ & $\mathrm{O}_{4}$ \\
\hline Franklinite & $\mathrm{Zn}$ & $\mathrm{Fe}_{2}$ & $\mathrm{O}_{4}$ \\
\hline Gahnite & $\mathrm{Zn}$ & $\mathrm{Al}_{2}$ & $\mathrm{O}_{4}$ \\
\hline Galaxite & $\mathrm{Mn}$ & $\mathrm{Al}_{2}$ & $\mathrm{O}_{4}$ \\
\hline Guite & Co & $\mathrm{Co}_{2}$ & $\mathrm{O}_{4}$ \\
\hline Hausmannite & $\mathrm{Mn}$ & $\mathrm{Mn}_{2}$ & $\mathrm{O}_{4}$ \\
\hline Hercynite & $\mathrm{Fe}$ & $\mathrm{Al}_{2}$ & $\mathrm{O}_{4}$ \\
\hline Hetaerolite & $\mathrm{Zn}$ & $\mathrm{Mn}_{2}$ & $\mathrm{O}_{4}$ \\
\hline Jacobsite & $\mathrm{Mn}$ & $\mathrm{Fe}_{2}$ & $\mathrm{O}_{4}$ \\
\hline Maghemite & $\left(\mathrm{Fe}_{0.67}^{3+} \square_{0.33}\right)$ & $\mathrm{Fe}_{2}$ & $\mathrm{O}_{4}$ \\
\hline Magnesiochromite & $\mathrm{Mg}$ & $\mathrm{Cr}_{2}$ & $\mathrm{O}_{4}$ \\
\hline Magnesiocoulsonite & $\mathrm{Mg}$ & $\mathrm{V}_{2}$ & $\mathrm{O}_{4}$ \\
\hline Magnesioferrite & $\mathrm{Mg}$ & $\mathrm{Fe}_{2}$ & $\mathrm{O}_{4}$ \\
\hline Magnetite & $\mathrm{Fe}$ & $\mathrm{Fe}_{2}$ & $\mathrm{O}_{4}$ \\
\hline Manganochromite & $\mathrm{Mn}$ & $\mathrm{Cr}_{2}$ & $\mathrm{O}_{4}$ \\
\hline Spinel & $\mathrm{Mg}$ & $\mathrm{Al}_{2}$ & $\mathrm{O}_{4}$ \\
\hline Thermaerogenite & $\mathrm{Cu}$ & $\mathrm{Al}_{2}$ & $\mathrm{O}_{4}$ \\
\hline Titanomaghemite & $\left(\mathrm{Ti}_{0.5}^{4+} \square_{0.5}\right)$ & $\mathrm{Fe}_{2}$ & $\mathrm{O}_{4}$ \\
\hline Trevorite & $\mathrm{Ni}$ & $\mathrm{Fe}_{2}$ & $\mathrm{O}_{4}$ \\
\hline Vuorelainenite & $\mathrm{Mn}$ & $\mathrm{V}_{2}$ & $\mathrm{O}_{4}$ \\
\hline Zincochromite & $\mathrm{Zn}$ & $\mathrm{Cr}_{2}$ & $\mathrm{O}_{4}$ \\
\hline Ulvöspinel subgroup (4-2) & $A^{4+}$ & $\mathbf{B}^{2+}$ & $\mathbf{X}$ \\
\hline Ahrensite & $\mathrm{Si}$ & $\mathrm{Fe}_{2}$ & $\mathrm{O}_{4}$ \\
\hline Brunogeierite & $\mathrm{Ge}$ & $\mathrm{Fe}_{2}$ & $\mathrm{O}_{4}$ \\
\hline Filipstadite & $\left(\mathrm{Fe}_{0.5}^{3+} \mathrm{Sb}_{0.5}^{5+}\right)$ & $\mathrm{Mn}_{2}$ & $\mathrm{O}_{4}$ \\
\hline Qandilite & $\mathrm{Ti}$ & $\mathrm{Mg}_{2}$ & $\mathrm{O}_{4}$ \\
\hline Ringwoodite & $\mathrm{Si}$ & $\mathrm{Mg}_{2}$ & $\mathrm{O}_{4}$ \\
\hline Tegengrenite & $\left(\mathrm{Mn}_{0.5}^{3+} \mathrm{Sb}_{0.5}^{5+}\right)$ & $\mathrm{Mg}_{2}$ & $\mathrm{O}_{4}$ \\
\hline Ulvöspinel & $\mathrm{Ti}$ & $\mathrm{Fe}_{2}$ & $\mathrm{O}_{4}$ \\
\hline
\end{tabular}

\begin{tabular}{|c|c|c|c|}
\hline \multicolumn{4}{|c|}{ Thiospinel group } \\
\hline Carrollite subgroup (1-3.5) & $\mathbf{A}^{1+}$ & $\mathbf{B}^{3.5+}$ & $\mathbf{x}$ \\
\hline Carrollite $^{\mathrm{a}}$ & $\mathrm{Cu}$ & $\mathrm{Co}_{2}$ & $\mathrm{~S}_{4}$ \\
\hline Cuproiridsite & $\mathrm{Cu}$ & $\left(\mathrm{Ir}^{3+} \mathrm{Ir}^{4+}\right)$ & $\mathrm{S}_{4}$ \\
\hline Cuprokalininite & $\mathrm{Cu}$ & $\left(\mathrm{Cr}^{3+} \mathrm{Cr}^{4+}\right)$ & $\mathrm{S}_{4}$ \\
\hline Fletcherite $^{\mathrm{a}}$ & $\mathrm{Cu}$ & $\mathrm{Ni}_{2}$ & $\mathrm{~S}_{4}^{+}$ \\
\hline Florensovite & $\mathrm{Cu}$ & $\left(\mathrm{Cr}_{1.5}^{3+} \mathrm{Sb}_{0.5}^{5+}\right)$ & $\mathrm{S}_{4}$ \\
\hline Malanite & $\mathrm{Cu}$ & $\left(\mathrm{Ir}^{3+} \mathrm{Pt}^{4+}\right)$ & $\mathrm{S}_{4}$ \\
\hline Rhodostannite & $\mathrm{Cu}$ & $\left(\mathrm{Fe}_{0.5}^{2+} \mathrm{Sn}_{1.5}^{4+}\right)$ & $\mathrm{S}_{4}$ \\
\hline Toyohaite & $\mathrm{Ag}$ & $\left(\mathrm{Fe}_{0.5}^{2+} \mathrm{Sn}_{1.5}^{4+}\right)$ & $\mathrm{S}_{4}$ \\
\hline Linnaeite subgroup (2-3) & $\mathrm{A}^{2+}$ & $\mathbf{B}^{3+}$ & $\mathbf{X}$ \\
\hline Cadmoindite & $\mathrm{Cd}$ & $\mathrm{In}_{2}$ & $\mathrm{~S}_{4}$ \\
\hline Cuprorhodsite & $\left(\mathrm{Cu}_{0.5}^{+} \mathrm{Fe}_{0.5}^{3+}\right)$ & $\mathrm{Rh}_{2}$ & $\mathrm{~S}_{4}$ \\
\hline Daubréelite & $\mathrm{Fe}$ & $\mathrm{Cr}_{2}$ & $\mathrm{~S}_{4}$ \\
\hline Greigite & $\mathrm{Fe}$ & $\mathrm{Fe}_{2}$ & $\mathrm{~S}_{4}$ \\
\hline Indite & $\mathrm{Fe}$ & $\mathrm{In}_{2}$ & $\mathrm{~S}_{4}$ \\
\hline Joegoldsteinite & $\mathrm{Mn}$ & $\mathrm{Cr}_{2}$ & $\mathrm{~S}_{4}$ \\
\hline Kalininite & $\mathrm{Zn}$ & $\mathrm{Cr}_{2}$ & $\mathrm{~S}_{4}$ \\
\hline Linnaeite & Co & $\mathrm{Co}_{2}$ & $\mathrm{~S}_{4}$ \\
\hline Polydymite & $\mathrm{Ni}$ & $\mathrm{Ni}_{2}$ & $\mathrm{~S}_{4}$ \\
\hline Siegenite & Co & $\mathrm{Ni}_{2}$ & $\mathrm{~S}_{4}$ \\
\hline Violarite & $\mathrm{Fe}$ & $\mathrm{Ni}_{2}$ & $\mathrm{~S}_{4}$ \\
\hline Xingzhongite & $\mathrm{Pb}$ & $\mathrm{Ir}_{2}$ & $\mathrm{~S}_{4}$ \\
\hline
\end{tabular}

Selenospinel group

\begin{tabular}{lccc}
\hline "Tyrrellite subgroup" (1-3.5) & $\mathbf{A}^{\mathbf{1 +}}$ & $\mathbf{B}^{\mathbf{3 . 5 +}}$ & $\mathbf{X}$ \\
Tyrrellita $^{\mathrm{a}}$ & $\mathrm{Cu}$ & $\left(\mathrm{Co}, \mathrm{Ni}_{2}\right.$ & $\mathrm{Se}_{4}$ \\
Bornhardtite subgroup (2-3) & $\mathbf{A}^{\mathbf{2 +}}$ & $\mathbf{B}^{\mathbf{3 +}}$ & $\mathbf{X}$ \\
Bornhardtite & $\mathrm{Co}$ & $\mathrm{Co}_{2}$ & $\mathrm{Se}_{4}$ \\
Trüstedtite & $\mathrm{Ni}$ & $\mathrm{Ni}_{2}$ & $\mathrm{Se}_{4}$ \\
\hline
\end{tabular}

${ }^{\mathrm{a}} \mathrm{See}$ discussion in the text. 


\begin{tabular}{|c|c|c|c|}
\hline \multirow{3}{*}{ Spinel supergroup } & Oxyspinel group & $\begin{array}{l}\text { Spinel subgroup (2-3) } \\
\text { Ulvöspinel subgroup (4-2) }\end{array}$ & $\begin{array}{l}\mathrm{A}^{2+}\left(\mathrm{B}^{3+}\right)_{2} \mathrm{O}_{4} \\
\mathrm{~A}^{4+}\left(\mathrm{B}^{2+}\right)_{2} \mathrm{O}_{4}\end{array}$ \\
\hline & Thiospinel group & $\begin{array}{l}\text { Carrollite subgroup (I-3.5) } \\
\text { Linnaeite subgroup (2-3) }\end{array}$ & $\begin{array}{l}\mathrm{A}^{1+}\left(\mathrm{B}^{3.5+}\right)_{2} \mathrm{~S}_{4} \\
\mathrm{~A}^{2+}\left(\mathrm{B}^{3+}\right)_{2} \mathrm{~S}_{4}\end{array}$ \\
\hline & Selenospinel group & $\begin{array}{l}\text { "Tyrrellite subgroup" (1-3.5) } \\
\text { Bornhardtite subgroup (2-3) }\end{array}$ & $\begin{array}{l}\mathrm{A}^{1+}\left(\mathrm{B}^{3.5+}\right)_{2} \mathrm{Se}_{4} \\
\mathrm{~A}^{2+}\left(\mathrm{B}^{3+}\right)_{2} \mathrm{Se}_{4}\end{array}$ \\
\hline
\end{tabular}

Fig. 2. The supergroup-group-subgroup hierarchy and general formulae of the spinels.

together in spinel, and each species is defined in a systematic fashion by stoichiometry, that is, on the basis of the chemical formula $\mathrm{AB}_{2} \mathrm{X}_{4}$.

In fact, the use of the structural formula, i.e. the application of the standard CNMNC guidelines (Nickel \& Grice, 1998) to each single crystallographic site to identify a spinel species, may lead to the creation of a surplus of end-members, which would be difficult to distinguish on a routine experimental basis and with little geological or petrological significance. For example, Nakatsuka et al. (2004) studied synthetic spinels along the series $\mathrm{Mg}\left(\mathrm{Al}_{2-x} \mathrm{Fe}_{x}^{3+}\right)_{\Sigma 2} \mathrm{O}_{4}$ and reported for the composition $x=1.21$ the structural formula: ${ }^{T}\left(\mathrm{Mg}_{0.38} \mathrm{Al}_{0.09} \mathrm{Fe}_{0.53}^{3+}\right)_{\Sigma 1.00}{ }^{M}\left(\mathrm{Mg}_{0.62} \mathrm{Al}_{0.70} \mathrm{Fe}_{0.68}^{3+}\right)_{\Sigma 2.00} \mathrm{O}_{4}$. According to Hawthorne (2002), the above formula shows that $\mathrm{Fe}^{3+}$ is dominant at the $T$ site and the pair $(\mathrm{Mg}+\mathrm{Al})^{\Sigma 5+}$ is dominant at the $M$ site, thus leading to end-member $\left(\mathrm{Fe}^{3+}\right)(\mathrm{MgAl}) \mathrm{O}_{4}$. The latter would represent a potential "intermediate" end-member between spinel and magnesioferrite $\left(\mathrm{MgAl}_{2} \mathrm{O}_{4}-\mathrm{MgFe}_{2} \mathrm{O}_{4}\right)$. Similar arguments apply to the magnetite-ulvöspinel series $\left(\mathrm{FeFe}_{2} \mathrm{O}_{4}-\mathrm{TiFe}_{2} \mathrm{O}_{4}\right)$, for which the "intermediate" end-member $\left(\mathrm{Fe}^{3+}\right)\left(\mathrm{Fe}_{1.5}^{2+} \mathrm{Ti}_{0.5}\right) \mathrm{O}_{4}$ is expected. Moreover, a classification scheme based on structural formulae will generate new species differing in their inversion parameter: e.g., the normal spinel ringwoodite $^{T}(\mathrm{Si})^{M}(\mathrm{Mg})_{2} \mathrm{O}_{4}$ would deserve a new name when occurring as inverse spinel ${ }^{T}(\mathrm{Mg})^{M}(\mathrm{MgSi}) \mathrm{O}_{4}$ (Bindi et al., 2018). All aforementioned examples encumber the development of consistent nomenclature system aimed at minimizing the proliferation of mineral names and identifying mineral species with relatively simple methods.

The total variations in spinel composition can easily be described by the ternary system $\mathrm{A}-\mathrm{B}-\mathrm{X}$, where parameters $A$ and $B$ show the greatest degree of variation. Once the $X$ is established, the system is reduced to a binary system A-B. The variation of these parameters is constrained by the electroneutrality principle, and therefore only one parameter is actually needed to identify the subgroup. This parameter is represented by the most abundant constituent $\mathrm{B}$ in the formula $\mathrm{AB}_{2} \mathrm{X}_{4}$. From chemical analytical data and in keeping with the dominant-valency rule (Hatert \& Burke, 2008), the dominant valence can be determined for B by summing the ions for each valence, e.g., $\Sigma R^{2+}=$ $\left(\mathrm{Mg}^{2+}+\mathrm{Fe}^{2+}+\mathrm{Mn}^{2+}\right)$ or $\Sigma R^{3+}=\left(\mathrm{Cr}^{3+}+\mathrm{Fe}^{3+}+\mathrm{Al}^{3+}\right)$.

Oxyspinels of subgroup 4-2 are characterized by $\Sigma R^{2+}>$ 1.5 atoms per formula unit (apfu), whereas oxyspinels of subgroup 2-3 are characterized by $\Sigma R^{3+}>1.0$ apfu. When $\Sigma R^{2+}>1.5$ apfu, $\Sigma R^{3+}<1$ apfu and vice versa.
Alternatively, the ratio $\Sigma R^{3+} / \Sigma R^{2+}$ can be used to distinguish between the two subgroups. This ratio varies from 0 to $2 / 3$ for spinel 4-2, and from $2 / 3$ to 2 for spinel 2-3. The special condition $\Sigma R^{3+} / \Sigma R^{2+}=2 / 3\left(\Sigma R^{2+}=1.5\right.$ apfu and $\Sigma R^{3+}=1.0$ apfu) corresponds to the boundary between spinels $4-2$ and 2-3 (e.g., $\left.\mathrm{Ti}_{0.5}^{4+} \mathrm{Fe}_{1.0}^{3+} \mathrm{Fe}_{1.5}^{2+} \mathrm{O}_{4}\right)$.

In order to avoid unrealistic end-member formulae, when $\Sigma R^{2+}>1.5$ apfu (subgroup 4-2), the B constituent is identified with $R^{2+}$ and the charge balance is achieved by coupling concentrations such as $\left(\mathrm{B}_{1.51}^{2+}\right)^{\Sigma 3.02+}$ with the charge arrangement $\left(\mathrm{A}_{1.0}^{\Sigma 4+} \mathrm{B}_{0.49}^{2+}\right)^{\Sigma 4.98+}$ : e.g., $\mathrm{Ti}_{1.0}^{4+} \mathrm{Fe}_{2.0}^{3+} \mathrm{O}_{4}$. On the other hand, when $\Sigma R^{3+}>1.0$ apfu (subgroup 2-3), $\mathrm{B}=R^{3+}$ and concentrations such as $\left(\mathrm{B}_{1.01}^{3+}\right)^{\Sigma 3.03+}$ will be consistent with the charge arrangement $\left(\mathrm{A}_{1.0}^{\Sigma 2+} \mathrm{B}_{0.99}^{3+}\right)^{\Sigma 4.97+}:$ e.g., $\mathrm{Fe}_{1.0}^{2+} \mathrm{Fe}_{2.0}^{3+} \mathrm{O}_{4}$. Once the valence of $\mathrm{B}$ is established, the dominant B-cation and then the dominant A-cation are identified according to the dominant-constituent rule. A possible difficulty is that as a result of charge balance requirements, some spinel end-members have A or B constituted by heterovalent pairs of ions (or ion + vacancy). For example, $A_{1.0}^{\Sigma 4+}$ and $\mathrm{A}_{1.0}^{\Sigma 2+} \mathrm{may}_{{ }^{\mathrm{A}}\left(\mathrm{Fe}_{0.5}^{3+} \mathrm{Sb}_{0.5}^{5+}\right)^{\Sigma 4+}}{ }_{\text {or }}{ }^{\mathrm{A}}\left(\mathrm{Mn}_{0.5}^{3+} \mathrm{Sb}_{0.5}^{5+}\right)^{\Sigma 4+}$ and ${ }^{\mathrm{A}}\left(\mathrm{Ti}_{0.5}^{4+} \square_{0.5}\right)^{\Sigma 2+}$ or ${ }^{\mathrm{A}}\left(\mathrm{Fe}_{0.67}^{3+} \square_{0.33}\right)^{\Sigma 2+}$, respectively. This mixed occupancy of A (or also of B) is consistent with the rule of the valency-imposed double site-occupancy (Hatert \& Burke, 2008).

\section{Issues in the classification of chalcospinels according to their cation charge arrangements}

The assignment of the oxidation states of oxyspinels can be considered relatively straightforward. On the other hand, the assignment of formal charges in chalcospinels (thiospinels and selenospinels) could have very little meaning (e.g., Goodenough, 1969), owing to the effects of electron delocalization and their possible non-stoichiometry (e.g., Vaughan \& Craig, 1978; Charnock et al., 1990). In addition, several transition elements occurring in $\mathrm{Cu}$ - and S-bearing compounds have two or more possible formal charges that need to be independently determined. In fact, they cannot be constrained by charge balance as the charge of $\mathrm{S}$ can assume non-integer values between -2 and -1 , due to the presence of holes in the S $3 p$ band (e.g., Riedel et al., 1981; Pattrick et al., 2008).

Actually, many thiospinels and selenospinels, characterized by the occurrence of $\mathrm{Cr}, \mathrm{Mn}, \mathrm{Fe}, \mathrm{Co}, \mathrm{Ni}, \mathrm{Zn}, \mathrm{Cd}$, and In, could be reasonably assigned to subgroup 2-3, i.e., cadmoindite $\left(\mathrm{Cd}^{2+} \mathrm{In}_{2}^{3+} \mathrm{S}_{4}\right)$, daubréelite $\left(\mathrm{Fe}^{2+} \mathrm{Cr}_{2}^{3+} \mathrm{S}_{4}\right)$, greigite $\left(\mathrm{Fe}^{2+} \mathrm{Fe}_{2}^{3+} \mathrm{S}_{4}\right)$, indite $\left(\mathrm{Fe}^{2+} \mathrm{In}_{2}^{3+} \mathrm{S}_{4}\right)$, joegoldsteinite $\left(\mathrm{Mn}^{2+} \mathrm{Cr}_{2}^{3+} \mathrm{S}_{4}\right)$, kalininite $\left(\mathrm{Zn}^{2+} \mathrm{Cr}_{2}^{3+} \mathrm{S}_{4}\right)$, linnaeite $\left(\mathrm{Co}^{2+}\right.$ $\left.\mathrm{Co}_{2}^{3+} \mathrm{S}_{4}\right)$, polydymite $\left(\mathrm{Ni}^{2+} \mathrm{Co}_{2}^{3+} \mathrm{S}_{4}\right)$, siegenite $\left(\mathrm{Co}^{2+} \mathrm{Ni}_{2}^{3+}\right.$ $\left.\mathrm{S}_{4}\right)$, trüstedtite $\left(\mathrm{Ni}^{2+} \mathrm{Ni}_{2}^{3+} \mathrm{Se}_{4}\right)$, violarite $\left(\mathrm{Fe}^{2+} \mathrm{Ni}_{2}^{3+} \mathrm{S}_{4}\right)$ and the questionable mineral bornhardtite $\left(\mathrm{Co}^{2+} \mathrm{Co}_{2}^{3+} \mathrm{Se}_{4}\right)$. Some of these assignments are supported by spectroscopic investigations (e.g., Vaughan \& Craig, 1985). 
However, the classification of $\mathrm{Cu}$-bearing chalcospinels is more problematic. In particular, the charge of ions in carrollite $\left(\mathrm{CuCo}_{2} \mathrm{~S}_{4}\right)$, fletcherite $\left(\mathrm{CuNi}_{2} \mathrm{~S}_{4}\right)$ and tyrrellite $\left[\mathrm{Cu}(\mathrm{Co}, \mathrm{Ni})_{2} \mathrm{Se}_{4}\right]$ is a matter of discussion. Indeed, $\mathrm{Cu}$ usually occurs as $\mathrm{Cu}^{1+}$ in sulfides, whereas $\mathrm{Cu}^{2+}$ is very rare. This notwithstanding, carrollite has been traditionally considered a 2-3 species, $\mathrm{Cu}^{2+} \mathrm{Co}_{2}^{3+}\left(\mathrm{S}^{2-}\right)_{4}$ (e.g., Charnock et al., 1990). Recently, Pattrick et al. (2008) and Buckley et al. (2009) investigated the formal charge of Co in carrollite through spectroscopic techniques. Both studies confirmed $\mathrm{Cu}^{1+}$, but the charge of $\mathrm{Co}$ is still under question. Pattrick et al. (2008) suggested a Co charge between +2 and +3 along with the charge-arrangement $\mathrm{Cu}^{1+}\left(\mathrm{Co}^{2+} \mathrm{Co}^{3+}\right)$ $\left(\mathrm{S}^{1.5-}\right)_{4}$. In contrast, Buckley et al. (2009), on the basis of a study by Wada et al. (2002), proposed a low-spin $\mathrm{Co}^{3+}$ with a charge for $\mathrm{S}$ only $12.5 \%$ less negative than -2 , which leads to the charge arrangement $\mathrm{Cu}^{1+} \mathrm{Co}_{2}^{3+}\left(\mathrm{S}^{1.75-}\right)_{4}$. With regard to fletcherite, there are only two studies (Craig \& Carpenter, 1977; Ostwald, 1985) that provide chemical data. To date, no information on the fletcherite structure and the formal charge of its constituents is available. With regard to tyrrellite, Yang et al. (2007) studied the crystal structure reporting a bond-valence sum value of 3.77 valence units for the $\mathrm{B}$ constituent $(\mathrm{Co}+\mathrm{Ni})$, which suggests that the $\mathrm{Co}$ or $\mathrm{Ni}$ ions would exist in a formal charge greater than $3+$. It was also concluded that $\mathrm{Cu}$ is +1 in tyrrellite by analogy with studies on $\mathrm{Cu}^{1+}\left(\mathrm{Cr}^{3+} \mathrm{Cr}^{4+}\right) \mathrm{Se}_{4}$ (e.g., Yang et al., 2007).

For classification purposes, the formal charges of the constituent elements in carrollite, fletcherite and tyrrellite are not crucial for their validity as mineral species, but merely for their inclusion in a subgroup. We are aware that further studies are needed in order to better define the formula of carrollite, fletcherite and tyrrellite. Presently, we assume that the oxidation states of anions ( $\mathrm{S}$ and $\mathrm{Se}$ ) and $\mathrm{Cu}$ are -2 and +1 (respectively). Such an assumption implies the occurrence of $\mathrm{Co}^{3+}, \mathrm{Co}^{4+}, \mathrm{Ni}^{3+}$ and $\mathrm{Ni}^{4+}$ which lead to $\mathrm{B}^{3.5+}$. As a result, carrollite, fletcherite and tyrrellite fall into subgroup 1-3.5. As the minimum requirement to have a mineral subgroup is that it contains at least two species (Mills et al., 2009), tyrrellite is considered as an isolated member of the potential "tyrrellite subgroup".

\section{Output of the recommended nomenclature}

In order to belong to the spinel supergroup, a mineral species has to have an atomic ratio between $(\mathrm{A}+\mathrm{B})$ cations (including vacancy) and $\mathrm{X}$ anions equal to $3: 4$, and a heteropolyhedral framework composed by $T \mathrm{X}_{4}$ tetrahedra isolated from each other and sharing corners with the neighboring $M \mathrm{X}_{6}$ octahedra. The latter, in turn, share six of their twelve $\mathrm{X}-\mathrm{X}$ edges with nearest-neighbor $M \mathrm{X}_{6}$. This supergroup is divided into three groups according to the dominant $\mathrm{X}$ species, i.e., oxyspinel group $\left(\mathrm{X}=\mathrm{O}^{2-}\right)$, thiospinel group $\left(X=S^{2-}\right)$, and selenospinel group $\left(X=\mathrm{Se}^{2-}\right)$. Within each group, many cation charge arrangement combinations are possible, constrained by the electroneutrality principle. Each of these combinations corresponds to a subgroup (Table 1).
The following spinels were redefined or discredited from the original description for internal consistency among the spinel species.

\subsection{Redefined spinel species}

\subsubsection{Titanomaghemite, redefined as $\left(\mathrm{Ti}_{0.5}^{4+} \square_{0.5}\right) \mathrm{Fe}_{2} \mathrm{O}_{4}$}

Titanomaghemite was reported as a questionable mineral in the IMA List of Minerals with the simplified formula $\mathrm{Fe}(\mathrm{Fe}, \mathrm{Ti})_{2} \mathrm{O}_{4}$. The latter did not reflect the occurrence of cation vacancies. Collyer et al. (1988) provided a detailed crystal-chemical characterization (EMPA, Mössbauer and SC-XRD) of a natural titanomaghemite sample from Pretoria, South Africa. The sample was refined in the space group $P_{3} 32$ and its empirical structural formula corresponds to ${ }^{T}\left(\mathrm{Fe}_{0.96}^{3+} \square_{0.04}\right)_{\Sigma 1.00}{ }^{M(1)}\left(\mathrm{Fe}_{0.03}^{2+} \mathrm{Fe}_{0.14}^{3+} \mathrm{Ti}_{0.06}^{4+} \square_{0.27}\right)_{\Sigma 0.50}{ }^{\mathrm{M}(2)}\left(\mathrm{Fe}_{0.20}^{2+}\right.$ $\left.\mathrm{Fe}_{0.85}^{3+} \mathrm{Ti}_{0.36}^{4+} \square_{0.10}\right)_{\Sigma 1.50} \mathrm{O}^{4}$, where $M(1)$ and $M(2)$ are two nonequivalent octahedrally coordinated sites. In accordance with Hawthorne (2002), this formula leads to the endmember composition:

${ }^{T}\left(\mathrm{Fe}^{3+}\right)^{M(1)}(\square)_{0.5}{ }^{M(2)}\left(\mathrm{Fe}_{1.0}^{3+} \mathrm{Ti}_{0.5}^{4+}\right) \mathrm{O}_{4}$ which in terms of A and $\mathrm{B}$ constituents can be rearranged as ${ }^{\mathrm{A}}\left(\square_{0.5} \mathrm{Ti}_{0.5}^{4+}\right)^{\Sigma 2+}$ ${ }^{\mathrm{B}}\left(\mathrm{Fe}_{2}^{3+}\right)^{\Sigma 6+/ 2=3+} \mathrm{O}_{4}=\left(\mathrm{Ti}_{0.5}^{4+} \square_{0.5}\right) \mathrm{Fe}_{2}^{3+} \mathrm{O}_{4}$. Titanomaghemite can hence be considered as a member of the spinel subgroup 2-3 of the oxyspinel group. The IMA status of titanomaghemite is consequently changed from $\mathrm{Q}$ (= questionable) to $\mathrm{Rd}$ (= redefined). The specimen "BM1929,1687'" kept in the Natural History Museum (London, UK) and used by Collyer et al. (1988) for their structural investigation is considered as the neotype material for titanomaghemite.

\subsubsection{Cuprorhodsite, redefined as $\left(\mathrm{Cu}_{0.5}^{I+} \mathrm{Fe}_{0.5}^{3+}\right) \mathrm{Rh}_{2}^{3+} \mathrm{S}_{4}$}

The formula of cuprorhodsite was reported as $\mathrm{CuRh}_{2} \mathrm{~S}_{4}$ in the IMA List of Minerals. However, reconsidering the empirical formula $\left(\mathrm{Cu}_{0.51} \mathrm{Fe}_{0.41}\right)\left(\mathrm{Rh}_{1.66} \mathrm{Ir}_{0.23} \mathrm{Pt}_{0.15}\right) \mathrm{S}_{4}$ (Rudashevsky et al., 1985) and the experimental data for synthetic thiospinels indicating the oxidation states $\mathrm{Cu}^{1+}$, $\mathrm{Fe}^{3+}$ and $\mathrm{Rh}^{3+}$ (Plumier \& Lotgering, 1970; Plumier et al., 1992), the ideal formula of cuprorhodsite can be redefined as $\left(\mathrm{Cu}_{0.5}^{1+} \mathrm{Fe}_{0.5}^{3+}\right) \mathrm{Rh}_{2}^{3+} \mathrm{S}_{4}$.

\subsubsection{Malanite, redefined as $\mathrm{Cu}^{1+}\left(\mathrm{Ir}^{3+} \mathrm{Pt}^{4+}\right) \mathrm{S}_{4}$}

The troubled history of malanite was briefly summarized by Biagioni \& Pasero (2014). On the basis of the study of $\mathrm{Yu}$ (1996), malanite was defined as $\mathrm{CuPt}_{2} \mathrm{~S}_{4}$ with $\mathrm{Pt}^{3+}$. However, the usual occurrence of $\mathrm{Cu}^{1+}$ in sulfides (e.g., Barkov et al., 2000) and the existence of the monoclinic synthetic compound $\mathrm{Cu}_{2}^{1+}\left(\mathrm{Pt}^{2+} \mathrm{Pt}_{3}^{4+}\right) \mathrm{S}_{8}$ (Gross \& Jansen, 1994) do not support the occurrence of $\mathrm{Pt}^{3+}$. In addition, natural occurrences of malanite are always rich in PGE other than Pt: for instance, the two chemical analyses reported in the type description ( $\mathrm{Yu}, 1996)$ correspond to $\left(\mathrm{Cu}_{0.93} \mathrm{Fe}_{0.06}\right)_{\Sigma 0.99}\left(\mathrm{Pt}_{1.03} \mathrm{Ir}_{0.66} \mathrm{Rh}_{0.04} \mathrm{Pd}_{0.03} \mathrm{Co}_{0.21} \mathrm{Ni}_{0.03}\right)_{\Sigma 2.00}$ $\mathrm{S}_{4.03}$ and $\left(\mathrm{Cu}_{0.95} \mathrm{Fe}_{0.07}\right)_{\Sigma 1.02}\left(\mathrm{Pt}_{1.37} \mathrm{Ir}_{0.45} \mathrm{Co}_{0.11} \mathrm{Rh}_{0.08}\right)_{\Sigma 2.01}$ $\mathrm{S}_{3.97}$. On the basis of arguments mentioned above, the ideal formula of malanite is consistent with $\mathrm{Cu}^{1+}\left(\mathrm{Ir}^{3+} \mathrm{Pt}^{4+}\right) \mathrm{S}_{4}$. 
Of particular interest in this regard is the composition of “dayingite" $\quad \mathrm{Cu}_{1.19}\left(\mathrm{Co}_{1.08} \mathrm{Pt}_{0.86}\right)_{\Sigma 1.94} \mathrm{~S}_{4.00} \quad(\mathrm{Yu}$ et al., 1974), described as a cobaltian malanite by $\mathrm{Yu}$ (1981), which would lead to the ideal formula $\mathrm{Cu}^{1+}\left(\mathrm{Co}^{3+} \mathrm{Pt}^{4+}\right) \mathrm{S}_{4}$. Barkov et al. (1997) described a Ni-malanite, corresponding to the ideal formula $\mathrm{Cu}^{1+}\left(\mathrm{Pt}_{1.5} \mathrm{Ni}_{0.5}^{2+}\right) \mathrm{S}_{4}$. Although no structural data are available for both $\mathrm{Co}-$ and $\mathrm{Ni}$-malanite varieties, these phases should be further investigated as potentially new species in the carrollite subgroup 1-3.5 of the thiospinel group.

\subsubsection{Maghemite, redefined as $\left(\mathrm{Fe}_{0.67}^{3+} \square_{0.33}\right) \mathrm{Fe}_{2} \mathrm{O}_{4}$}

The IMA List of Minerals gave for maghemite the formula $\mathrm{Fe}_{2} \mathrm{O}_{3}$. However, it is convenient to rewrite it as $\left(\mathrm{Fe}_{0.67}^{3+} \square_{0.33}\right) \mathrm{Fe}_{2}^{3+} \mathrm{O}_{4}$, which better reflects its relation to the spinel supergroup. The presence of cation vacancies is a result of the oxidation of magnetite, to which maghemite is structurally related. Depending on the degree of vacancy ordering, maghemite can crystallize in space group $F d \overline{3} m$ (vacancies randomly distributed), $P 4_{1} 32$ (vacancies partially ordered), or $P 4_{1} 22_{1}$, in a tetragonal multiple cell with $c=3 a$ (vacancies completely ordered) (e.g., Greaves, 1983; Shmakov et al., 1995; Jørgensen et al., 2007; Bowles et al., 2011).

Similar arguments apply to the Al-analogue of maghemite, deltalumite, whose space group is $P \overline{4} m 2$ (Pekov et al., 2016) and whose formula can be written as $\left(\mathrm{Al}_{0.67} \square_{0.33}\right) \mathrm{Al}_{2} \mathrm{O}_{4}$.

\subsubsection{Filipstadite, redefined as $\left(\mathrm{Fe}_{0.5}^{3+} \mathrm{Sb}_{0.5}^{5+}\right) \mathrm{Mn}_{2} \mathrm{O}_{4}$}

Filipstadite was reported in the IMA List of Minerals with the simplified formula $\left(\mathrm{Mn}^{2+}, \mathrm{Mg}\right)_{2}\left(\mathrm{Sb}^{5+}, \mathrm{Fe}^{3+}\right) \mathrm{O}_{4}$, which could be resolved into the two potential end-members: $\mathrm{Mg}_{2}\left(\mathrm{Sb}_{0.5}^{5+} \mathrm{Fe}_{0.5}^{3+}\right) \mathrm{O}_{4}$ and $\mathrm{Mn}_{2}^{2+}\left(\mathrm{Sb}_{0.5}^{5+} \mathrm{Fe}_{0.5}^{3+}\right) \mathrm{O}_{4}$. The latter was proposed by Dunn et al. (1988) as the ideal formula for filipstadite.

This rare mineral was found in Långban, Sweden, and crystallizes in the space group $F d \overline{3} m$ with a spinel-type superstructure: $a=25.93 \AA, Z=216$ (Bonazzi et al., 2013). Due to cation ordering, the structure comprises 11 distinct cation sites and 10 distinct anion sites. Due to the complex cation allocation at each independent site, Bonazzi et al. (2013) grouped the $T(1-5)$ and $M(1-6)$ sites and provided the empirical formula: ${ }^{T}\left(\mathrm{Mn}_{0.60}^{2+} \mathrm{Mg}_{0.07} \mathrm{Fe}_{0.30}^{3+}\right.$ $\left.\mathrm{Zn}_{0.02} \mathrm{Si}_{0.01}\right)_{\Sigma 1.00}{ }^{M}\left(\mathrm{Mn}_{0.56}^{2+} \mathrm{Mg}_{0.76} \mathrm{Fe}_{0.16}^{3+} \mathrm{Al}_{0.02} \mathrm{Sb}_{0.50}^{5+}\right)_{\Sigma 2.00} \mathrm{O}_{4}$.

The latter would lead to the end-member formula ${ }^{T}\left(\mathrm{Mn}_{0.5}^{2+} \mathrm{Fe}_{0.5}^{3+}\right)^{M}\left(\mathrm{Mg}_{1.5} \mathrm{Sb}_{0.5}^{5+}\right) \mathrm{O}_{4}$, which, however, does not reflect the empirical composition as it underestimates the actual $\mathrm{Mn}^{2+}$ content (always > $1.1 \mathrm{apfu}$ ) and overestimates the Mg content. By considering only the chemical information, the populations of the $T$ and $M$ sites may be merged and the chemical formula expressed as: ${ }^{T+M}\left(\mathrm{Mn}_{1.16}^{2+} \mathrm{Mg}_{0.83} \mathrm{Fe}_{0.46}^{3+} \mathrm{Sb}_{0.50}^{5+} \mathrm{Zn}_{0.02} \mathrm{Al}_{0.02} \mathrm{Si}_{0.01}^{4+}\right)_{\Sigma 3.00} \mathrm{O}_{4}$. This formula highlights the dominance of divalent cations, $\Sigma R^{2+}\left(\mathrm{Mn}^{2+}+\mathrm{Mg}+\mathrm{Zn}\right)=2.01$ apfu $(>1.5$ apfu $)$, indicating that filipstadite can be classified in the spinel subgroup 4-2 of the oxyspinel group: the constituent $\mathrm{B}=\mathrm{Mn}^{2+}$, which dominates over $\mathrm{Mg}$ and $\mathrm{Zn}$, and $\mathrm{A}=\left(\mathrm{Fe}_{0.5}^{3+} \mathrm{Sb}_{0.5}^{5+}\right)$. The corresponding ideal formula of filipstadite is therefore consistent with that proposed by Dunn et al. (1988): ${ }^{A}\left(\mathrm{Fe}_{0.5}^{3+} \mathrm{Sb}_{0.5}^{5+}\right)^{B}\left(\mathrm{Mn}^{2+}\right)_{2} \mathrm{O}_{4}$.

\subsubsection{Tegengrenite, redefined as $\left(\mathrm{Mn}_{0.5}^{3+} \mathrm{Sb}_{0.5}^{5+}\right) \mathrm{Mg}_{2} \mathrm{O}_{4}$}

Tegengrenite was reported in the IMA List of Minerals with the simplified formula $\mathrm{Mg}_{2}(\mathrm{Sb}, \mathrm{Mn}) \mathrm{O}_{4}$. Charge balance requirements indicate that the ideal formula is $\left(\mathrm{Mn}_{0.5}^{3+} \mathrm{Sb}_{0.5}^{5+}\right) \mathrm{Mg}_{2} \mathrm{O}_{4}$.

Tegengrenite is a rare mineral considered to be a $\mathrm{Mg}-\mathrm{Mn}^{3+}$ analogue of filipstadite having a rhombohedrally distorted spinel-type structure (Holtstam \& Larsson, 2000). Bonazzi \& Bindi (2015) refined the crystal structure of a sample from the Filipstad district (Värmland, Sweden) in the trigonal space group $R 3$ and showed that the tegengrenite superstructure has a close structural relationship to spinel. Owing to cation ordering, the $M$ and $T$ sites of the structure are split into ten and six independent sites, respectively.

Similarly, to filipstadite, the site allocation of cations in the tegengrenite superstructure is also quite complex. According to the two empirical formulae reported in literature, $\left(\mathrm{Mg}_{1.22} \mathrm{Mn}_{0.82}^{2+} \mathrm{Zn}_{0.07} \mathrm{Mn}_{0.23}^{3+} \mathrm{Fe}_{0.02}^{3+} \mathrm{Al}_{0.03} \mathrm{Si}_{0.06} \mathrm{Ti}_{0.04} \mathrm{Sb}_{0.50}^{5+}\right) \mathrm{O}_{4}$ (Holtstam \& Larsson, 2000) and $\left(\mathrm{Mg}_{1.26} \mathrm{Mn}_{0.85}^{2+}\right.$ $\left.\mathrm{Zn}_{0.04} \mathrm{Mn}_{0.19}^{3+} \mathrm{Al}_{0.01} \mathrm{Si}_{0.12} \mathrm{Ti}_{0.03} \mathrm{Sb}_{0.50}^{5+}\right) \mathrm{O}_{4}$ (Bonazzi \& Bindi, 2015), the divalent cations $\left(\mathrm{Mg}+\mathrm{Mn}^{2+}+\mathrm{Zn}=2.15 \mathrm{apfu}\right)$ are dominant and indicate that tegengrenite belongs to subgroup 4-2. The constituent $\mathrm{B}$ is represented by $\mathrm{Mg}^{2+}$, whereas $\mathrm{A}$ is represented by $\left(\mathrm{Mn}_{0.5}^{3+} \mathrm{Sb}_{0.50}^{5+}\right)^{\Sigma=4+}$ for charge balance reasons. Therefore, the ideal formula of the tegengrenite is $\left(\mathrm{Mn}_{0.5}^{3+} \mathrm{Sb}_{0.50}^{5+}\right)^{\Sigma=4+} \mathrm{Mg}_{2} \mathrm{O}_{4}$.

\subsubsection{Rhodostannite, redefined as $\mathrm{Cu}^{l+}\left(\mathrm{Fe}_{0.5}^{2+} \mathrm{Sn}_{1.5}^{4+}\right) \mathrm{S}_{4}$}

Rhodostannite is a sulfide mineral that was first described by Springer (1968) with the formula $\mathrm{Cu}_{2} \mathrm{FeSn}_{3} \mathrm{~S}_{8}$ (specimen from Vila Apacheta, Bolivia). Rhodostannite was included in the IMA List of Minerals with the simplified formula $(\mathrm{Cu}, \mathrm{Ag})_{2} \mathrm{FeSn}_{3} \mathrm{~S}_{8}$, which is too generalized to indicate what the distinction is between rhodostannite and toyohaite. In fact, such a formula could be resolved into two end-member formulae, i.e., $\mathrm{Cu}_{2} \mathrm{FeSn}_{3} \mathrm{~S}_{8}$ and $\mathrm{Ag}_{2} \mathrm{FeSn}_{3} \mathrm{~S}_{8}$ (toyohaite).

Rhodostannite is included in the spinel supergroup because of its spinel-related structure and typical cation-to-anion ratio of 3:4. Jumas et al. (1979) determined by SC-XRD the crystal structure of rhodostannite in the space group $I 4_{1} / a$. Copper is monovalent and occupies the $T$ site, whereas $\mathrm{Fe}$ and Sn are randomly distributed over the equivalent $M$ sites. Garg et al. (2001) determined by ${ }^{57} \mathrm{Fe}$ and ${ }^{119} \mathrm{Sn}$ Mössbauer spectroscopy the valence states of iron $\left(\mathrm{Fe}^{2+}\right)$ and tin $\left(\mathrm{Sn}^{4+}\right)$.

In accordance with Jumas et al. (1979), the ideal formula of rhodostannite should be written as $\mathrm{Cu}\left(\mathrm{Fe}_{0.5} \mathrm{Sn}_{1.5}\right) \mathrm{S}_{4}$ to better show its relationship to the spinel supergroup. $\mathrm{As}_{\mathrm{Cu}^{1+}}=\mathrm{A}^{1+}$ and $\left(\mathrm{Fe}_{0.5}^{2+} \mathrm{Sn}_{1.5}^{4+}\right)^{\Sigma=7+}=2 \mathrm{~B}^{3.5+}$, rhodostannite belongs to the carrollite subgroup 1-3.5 of the thiospinel group. 


\subsubsection{Toyohaite, redefined as $\mathrm{Ag}^{1+}\left(\mathrm{Fe}_{0.5}^{2+} \mathrm{Sn}_{1.5}^{4+}\right) \mathrm{S}_{4}$}

Toyohaite is the $\mathrm{Ag}$ analogue of rhodostannite described by Yajima et al. (1991) in the tetragonal space group $I 4_{1} / a$. The ideal formula $\mathrm{Ag}_{2} \mathrm{FeSn}_{3} \mathrm{~S}_{8}$ is revised as $\mathrm{Ag}\left(\mathrm{Fe}_{0.5} \mathrm{Sn}_{1.5}\right) \mathrm{S}_{4}$ to better highlight its relation to the spinel supergroup.

\subsubsection{Xingzhongite, redefined as $\mathrm{Pb}^{2+} \mathrm{Ir}_{2}^{3+} S_{4}$}

Xingzhongite was reported in the IMA List of Minerals with the simplified formula $(\mathrm{Pb}, \mathrm{Cu}, \mathrm{Fe}) \mathrm{Ir}_{2} \mathrm{~S}_{4}$ and questionable IMA status. Its empirical formula, $\left(\mathrm{Pb}_{0.37} \mathrm{Cu}_{0.35} \mathrm{Fe}_{0.17}\right)_{\Sigma 0.89}$ $\left(\mathrm{Ir}_{1.33} \mathrm{Rh}_{0.41} \mathrm{Pt}_{0.29}\right)_{\Sigma 2.03} \mathrm{~S}_{4}$ (Yu et al., 1974), leads to the ideal one $\mathrm{Pb}^{2+} \mathrm{Ir}_{2}^{3+} \mathrm{S}_{4}$, although its status as a mineral species still remains questionable.

\subsection{Discredited spinel species}

\subsection{1. "Iwakiite", discredited as a polymorph of jacobsite}

Iwakiite was first described by Matsubara et al. (1979) with the approximate empirical formula ${ }^{T}\left(\mathrm{Mn}^{2+}\right)_{\Sigma 1.0}$ ${ }^{M}\left(\mathrm{Fe}_{1.3}^{3+} \mathrm{Mn}_{0.7}^{3+}\right)_{\Sigma 2.0} \mathrm{O}_{4}$ and tetragonal space group $P 4_{2} / n n m$, subsequently corrected as I4 ${ }_{1}$ amd by Jarosch (1987). Departure from the cubic symmetry is ascribed to the bond-length distortion of the octahedron, related to the ${ }^{M} \mathrm{Mn}^{3+}$ content. This notwithstanding, the empirical formula of iwakiite leads to an end-member formula identical to that of jacobsite: ${ }^{T}\left(\mathrm{Mn}^{2+}\right)^{M}\left(\mathrm{Fe}_{2}^{3+}\right) \mathrm{O}_{4}$. In accord with the definition of polymorphism of Nickel \& Grice (1998), which is not restricted to substances with identical chemical compositions, but can be broadened somewhat to include relatively minor chemical variations when the topology of the structure is retained, iwakiite is considered as the tetragonal dimorph of jacobsite. Accordingly, iwakiite and jacobsite are regarded as polymorphs. Since jacobsite was discovered earlier than iwakiite, the former name is retained. Tetragonal "iwakiite" is hence referred as jacobsite- $Q$.

Similar arguments apply to the natural ( $\mathrm{Zn}, \mathrm{Mn})$ ferrite (Bailadores region, Mérida, Venezuela), refined by Marcano et al. (1996) in the space group I4 1 /amd. Its chemical composition $\left(\mathrm{Zn}_{0.75} \mathrm{Mn}_{0.75} \mathrm{Fe}_{1.50} \mathrm{O}_{4}\right)$ can be converted to the structural formula ${ }^{T}\left(\mathrm{Zn}_{0.75} \mathrm{Mn}_{0.25}^{2+}\right)_{\Sigma 1.00}$ ${ }^{M}\left(\mathrm{Mn}_{0.50}^{2+} \mathrm{Fe}_{1.50}^{3+}\right)_{\Sigma 2.00} \mathrm{O}_{4}$, which leads to the end-member $\mathrm{ZnFe}_{2}^{3+} \mathrm{O}_{4}$. Because of the tetragonal symmetry due to the Jahn-Teller effect of ${ }^{M} \mathrm{Mn}^{3+}$, this mineral can be considered as a tetragonal dimorph of franklinite, and thus termed as franklinite- $Q$.

\subsection{2. "Hydrohetaerolite", discredited as corresponding to hetaerolite}

Hydrohetaerolite was listed as a valid species in the IMA List of Minerals with the formula $\mathrm{HZnMn}_{1.7}^{3+} \mathrm{O}_{4}$. It was first reported by Palache (1928) as a hydrous counterpart of hetaerolite, $\mathrm{ZnMn}_{2}^{3+} \mathrm{O}_{4}$. McAndrew (1956) showed that the X-ray powder pattern of hydrohetaerolite is consistent with the tetragonal space group I4 1 /amd $(a=5.73 \AA, c=$ $9.00 \AA, Z=4$ ), and pointed out the presence of cation vacancies. No structural data have been presented for hydrohetaerolite. As water should occur as $(\mathrm{OH})^{1-}$ in the spinel structure (e.g., Lenaz et al., 2008), the formula of hydrohetaerolite can be recalculated by taking into account cation vacancies and $(\mathrm{OH})$ groups. Thus, for example, the chemical formula $\mathrm{HZnMn}_{1.6}^{3+} \square_{0.4} \mathrm{O}_{4}$, proposed by McAndrew (1956) for a sample from Leadville (Colorado, USA), can be rearranged as $\mathrm{ZnMn}_{1.6}^{3+} \square_{0.4}\left[\mathrm{O}_{3}(\mathrm{OH})\right]$. Meisser \& Perseil (1993) reported three chemical analyses of hydrohetaerolite from the Chez Larze Mine, Mont Chemin (Valais, Switzerland), containing 4-6.3 wt $\% \mathrm{H}_{2} \mathrm{O}$, resulting in the formula $\mathrm{H}_{1.27}\left(\mathrm{Zn}_{0.68} \mathrm{Cu}_{0.03}^{2+}\right)\left(\mathrm{Mn}_{1.68}^{3+} \mathrm{Si}_{0.05}\right) \mathrm{O}_{4}$, which can be rearranged as $\left(\mathrm{Zn}_{0.68} \mathrm{Cu}_{0.03}^{2+}\right) \square_{0.56}\left(\mathrm{Mn}_{1.68}^{3+} \mathrm{Si}_{0.05}\right)\left[\mathrm{O}_{2.73}(\mathrm{OH})_{1.27}\right]$.

All these formulae are consistent with the endmember $\mathrm{ZnMn}_{2} \mathrm{O}_{4}$ because the dominant anion is always $\mathrm{O}^{2-}(>\mathrm{OH})$ and $\mathrm{Mn}^{3+}>(\mathrm{Zn}+\mathrm{Cu})^{2+}>\square$. Therefore, "hydrohetaerolite" is discredited as corresponding to $(\mathrm{OH})$-bearing hetaerolite.

\subsection{3. "Ferrorhodsite", discredited as corresponding to cuprorhodsite}

The chemical formula of ferrorhodsite was reported as $\mathrm{FeRh}_{2} \mathrm{~S}_{4}$ in the IMA List of Minerals. Ferrorhodsite was described as the $\mathrm{Fe}$ analogue of cuprorhodsite, with empirical formulae $\left(\mathrm{Fe}_{0.57} \mathrm{Cu}_{0.42}\right)_{\Sigma 0.99}\left(\mathrm{Rh}_{1.72} \mathrm{Ir}_{0.23} \mathrm{Pt}_{0.05}\right)_{\Sigma 2.00} \mathrm{~S}_{4}$ and $\quad\left(\mathrm{Fe}_{0.52} \mathrm{Cu}_{0.48} \mathrm{Ni}_{0.03}\right)_{\Sigma 1.03}\left(\mathrm{Rh}_{1.67} \mathrm{Pt}_{0.16} \mathrm{Ir}_{0.13}\right)_{\Sigma 1.96} \mathrm{~S}_{4}$ (Rudashevsky et al., 1998). However, these formulae lead to the ideal formula of cuprorhodsite $\left(\mathrm{Cu}_{0.5}^{1+} \mathrm{Fe}_{0.5}^{3+}\right) \mathrm{Rh}^{3+} \mathrm{S}_{4}$. Therefore, ferrorhodsite is discredited as corresponding to cuprorhodsite, with a slightly different $\mathrm{Fe} / \mathrm{Cu}$ atomic ratio. As cuprorhodsite was described earlier than "ferrorhodsite", the former name is retained.

\section{Applying the nomenclature of the spinel supergroup: some examples}

For classification purposes, each spinel-supergroup species is identified by the chemical formula $\mathrm{AB}_{2} \mathrm{X}_{4}$. Once the chemical composition of a mineral has been established, it can be placed in the oxy-, thio- or seleno-spinel group. The dominant primary parameter B defines the subgroup and, along with the secondary parameter A, is used to identify the species. In detail, the following systematic procedure for naming spinel-supergroup species is suggested:

1) Identify the group by the composition of $X$.

2) Identify the most abundant constituent $B$ by summing the ions for each valence: e.g., $\Sigma R^{2+}=\left(\mathrm{Mg}^{2+}+\mathrm{Fe}^{2+}\right.$ $\left.+\mathrm{Mn}^{2+}\right)>1.5$ apfu leads to $\mathrm{B}^{2+}$, whereas $\Sigma R^{3+}=$ $\left(\mathrm{Cr}^{3+}+\mathrm{Fe}^{3+}+\mathrm{Al}^{3+}\right)>1.0$ apfu leads to $\mathrm{B}^{3+}$.

3) Identify the subgroup by the constituent $\mathrm{B}:$ e.g., for $\mathrm{B}^{3+}$ $\left(\Sigma R^{3+}>1.0\right.$ apfu $)$ the species belongs to subgroup 2-3 $\left(\mathrm{A}^{2+} \mathrm{B}_{2}^{3+} \mathrm{O}_{4}\right)$; for $\mathrm{B}^{2+}\left(\Sigma R^{2+}>1.5\right.$ apfu $)$ the species belongs to the subgroup 4-2 $\left(\mathrm{A}^{4+} \mathrm{B}_{2}^{2+} \mathrm{O}_{4}\right)$. Alternatively, the $\Sigma R^{3+} / \Sigma R^{2+}$ ratio can be used to identify the subgroups: it varies from 0 to $2 / 3$ for spinel $4-2$, and from $2 / 3$ to 2 for spinel 2-3.

4) Once the valence of $B$ is established, the dominant B-cation and subsequently the dominant A-cation are identified according to the dominant-constituent rule, 
in which heterovalent pairs of ions (or ion and vacancy) have to be considered for classification purposes.

Some examples referring to the oxyspinel group are given below, including synthetic spinels because they provide instructive examples.

Example 1. Bosi et al. (2009) reported a synthetic spinel (sample FeTi30A) with chemical formula $\left(\mathrm{Fe}_{1.46}^{2+} \mathrm{Fe}_{1.08}^{3+}\right.$ $\left.\mathrm{Ti}_{0.46}^{4+}\right)_{\Sigma 3.00} \mathrm{O}_{4}$. Such a composition is very close to the boundary between magnetite and ulvöspinel $\left(\mathrm{Ti}_{0.5} \mathrm{Fe}_{10}^{3+}\right.$ $\left.\mathrm{Fe}_{1.5}^{2+} \mathrm{O}_{4}\right)$ and has $\Sigma R^{3+}=\mathrm{Fe}^{3+}>1.0$ apfu, and $\Sigma R^{2+}=$ $\mathrm{Fe}^{2+5}<1.5$ apfu $\left(\Sigma R^{3+} / \Sigma R^{2+}=0.74\right)$. Thus, $\mathrm{B}$ is $3+$ and the species belongs to the subgroup 2-3: $\left(\mathrm{A}^{2+} \mathrm{B}_{2}^{3+} \mathrm{O}_{4}\right)$. As the dominant $\mathrm{B}$-cation is $\mathrm{Fe}^{3+}$ and the dominant A-cation is $\mathrm{Fe}^{2+}$, the composition $\left(\mathrm{Fe}_{146}^{2+} \mathrm{Fe}_{1.08}^{3+} \mathrm{Ti}_{0.46}^{4+}\right)_{\Sigma 3.00} \mathrm{O}_{4}$ leads to the ideal formula ${ }^{\mathrm{A}}\left(\mathrm{Fe}^{2+}\right)^{\mathrm{B}}\left(\mathrm{Fe}^{3+}\right)_{2} \mathrm{O}_{4}$, i.e., magnetite.

Example 2. Similarly, sample FeTi50Bb (Bosi et al., 2009) is characterized by $1.59 \mathrm{Fe}^{2+}, 0.80 \mathrm{Fe}^{3+}, 0.03 \mathrm{Al}^{3+}$ and 0.59 $\mathrm{Ti}^{4+}$ apfu, with $\Sigma R^{3+}\left(=\mathrm{Fe}^{3+}+\mathrm{Al}^{3+}\right)=0.83$ apfu $(<1$ apfu $)$ and $\Sigma R^{2+}=\mathrm{Fe}^{2+}>1.5$ apfu $\left(\Sigma R^{3+} / \Sigma R^{2+}=0.52\right)$. Thus, $\mathrm{B}$ is $2+$ and the species belongs to the subgroup 4-2: $\mathrm{A}^{4+} \mathrm{B}_{2}^{2+} \mathrm{O}_{4}$. As the dominant B-cation is $\mathrm{Fe}^{2+}$ and the dominant A-cation is $\mathrm{Ti}^{4+}$, the empirical composition $\left(\mathrm{Fe}_{1.59}^{2+} \mathrm{Fe}_{0.80}^{3+} \mathrm{Al}_{0.03}^{3+} \mathrm{Ti}_{0.59}^{4+}\right)_{\Sigma 3.00} \mathrm{O}_{4}$ leads to the ideal formula

${ }^{\mathrm{A}}\left(\mathrm{Ti}^{4+}\right)^{\mathrm{B}}\left(\mathrm{Fe}^{2+}\right)^{2} \mathrm{O}^{4}$, i.e., ulvöspinel.

Example 3. Lenaz et al. (2011) reported a natural spinel from the Rum Layered Suite, NW Scotland (sample RumBAn2), with chemical formula ${ }^{T+M}\left(\mathrm{Fe}_{0.9}^{2+} \mathrm{Mg}_{0.14} \mathrm{Ni}_{0.01} \mathrm{Mn}_{0.01} \mathrm{Fe}_{0.76}^{3+} \mathrm{Cr}_{0.71} \mathrm{Al}_{0.38} \mathrm{~V}_{0.02} \mathrm{Ti}_{0.07}\right) \mathrm{O}_{4}$. The sum of trivalent cations $\Sigma R^{3+}(=\mathrm{Fe}+\mathrm{Cr}+\mathrm{Al}+\mathrm{V})$ is $1.87 \mathrm{apfu}$, and the sum of divalent cations $\Sigma R^{2+}(=\mathrm{Fe}+$ $\mathrm{Mg}+\mathrm{Ni}+\mathrm{Mn})$ is 1.07 apfu. As $\Sigma R^{3+}>1.0$ apfu, and $\Sigma R^{2+}<1.5$ apfu $\left(\Sigma R^{3+} / \Sigma R^{2+}=1.75\right)$, the sample belongs to subgroup 2-3. Becauset the dominant $R^{3+}$ cation is $\mathrm{Fe}^{3+}$ $(=\mathrm{B})$ and the dominant $R$ cation is $\mathrm{Fe}^{2+}(=\mathrm{A})$, the species is identified as magnetite.

Example 4. Oktyabrsky et al. (1992) reported chemical analyses of spinels rich in $\mathrm{Mg}, \mathrm{Fe}$, and $\mathrm{Ti}$ from Kondyor, Russia. Their analysis \#3 corresponds to the following chemical formula: $\left(\mathrm{Fe}_{0.04}^{2+} \mathrm{Mg}_{1.37} \mathrm{Mn}_{0.07}^{2+} \mathrm{Fe}_{0.88}^{3+} \mathrm{Al}_{0.17} \mathrm{Ti}_{0.47}\right) \mathrm{O}_{4}$. As the sum of trivalent cations $\Sigma R^{3+}(=\mathrm{Fe}+\mathrm{Al})$ is 1.05 apfu (>1.0 apfu) and the sum of divalent cations $\Sigma R^{2+}$ $(=\mathrm{Fe}+\mathrm{Mg}+\mathrm{Mn})$ is 1.47 apfu $(<1.5$ apfu $)\left(\Sigma R / \Sigma R^{2+}=\right.$ 0.72 ), this sample+belongs to subgroup 2-3. The dominant $R^{3+}$ eation is $\mathrm{Fe} \quad(=\mathrm{B})$ and the dominant $R^{2+}$ cation is $\mathrm{Mg}$ (= A), thus the species is identified as magnesioferrite, although the proportion of end-member components indicate that $\mathrm{TiMg}^{2} \mathrm{O}^{4}(45.5 \%)>\mathrm{MgFe}_{2}^{3+} \mathrm{O}_{4}$ (44.0\%). Similarly, Mitchell (1995) reported representative compositions of spinels from the Besterskraal, Sover North, and Pniel orangeites. Based on the dominant-end-member approach, analysis \#1 (Table 2.27 of Mitchell, 1995) was identified as chromite: $\mathrm{FeCr}^{2} \mathrm{O}^{4}(42.6 \%)>\mathrm{MgCr}^{2} \mathrm{O}^{4}$ $(39.4 \%)>\mathrm{MgAl}^{2} \mathrm{O}^{4}(6.6 \%)>\mathrm{FeFe}^{2} \mathrm{O}^{4}(5.7 \%)>\mathrm{Mg}^{2} \mathrm{TiO}^{4}$ $(3.9 \%)>\mathrm{MnCr}^{2} \mathrm{O}^{4}(1.9 \%)$. However, the corresponding chemical formula, $\left(\mathrm{Fe}_{0.48}^{2+} \mathrm{Mg}_{0.53} \mathrm{Mn}_{0.02}^{2+} \mathrm{Fe}_{0.08}^{3+} \mathrm{Al}_{0.13} \mathrm{Cr}_{1.73}\right.$ $\left.\mathrm{Ti}_{0.03}\right) \mathrm{O}_{4}$, is consistent with magnesiochromite as the dominant $R_{3+}$ cation is $\mathrm{Cr}(=\mathrm{B})$ and the dominant $R_{2+}$ cation is $\mathrm{Mg}_{2+}(=\mathrm{A})$.

Although the subdivision of a mineral composition into end-member proportions is an important step for application of thermodynamics to mineral systems, the two spinel compositions mentioned in Example 4 show that identifying a mineral species on the proportion of end-member components may be ambiguous and should not be applied to mineral nomenclature (Bosi, 2018).

Acknowledgements: We are grateful to the IMACNMNC members for their suggestions on the nomenclature proposal, and to the CNMNC vice-chairman (F. Hatert) for handling the whole procedure. We thank M.E. Ciriotti, for his help in finding mineral species related to spinel, A.R. Chakhmouradian and an anonymous reviewer for their helpful comments.

\section{References}

Andreozzi, G.B. \& Princivalle, F. (2002): Kinetics of cation ordering in synthetic $\mathrm{MgAl}_{2} \mathrm{O}_{4}$ spinel. Am. Mineral., 87, 838-844.

Andreozzi, G.B., Princivalle, F., Skogby, H., Della Giusta, A. (2000): Cation ordering and structural variations with temperature in $\mathrm{MgAl}_{2} \mathrm{O}_{4}$ spinel: An X-ray single crystal study. Am. Mineral., 85, 1164-1171.

Barkov, A.Y., Halkoaho, T.A.A., Laajoki, K.V.O., Alapieti, T.T., Peura, R.A. (1997): Ruthenian pyrite and nickeloan malanite from the Imandra layered complex, northwestern Russia. Can. Mineral., 35, 887-897.

Barkov, A.Y., Martin, R.F., Halkoaho, T.A.A., Poirier, G. (2000): The mechanism of charge compensation in $\mathrm{Cu}-\mathrm{Fe}-\mathrm{PGE}$ thiospinels from the Penikat layered intrusion, Finland. Am. Mineral., 85, 694-697.

Biagioni, C. \& Pasero, M. (2014): The systematics of the spinel-type minerals: an overview. Am. Mineral., 99, 1254-1264.

Bindi, L., Griffin, W.L., Panero, W.R., Sirotkina, E., Bobrov, A., Irifune, T. (2018): Synthesis of inverse ringwoodite sheds light on the subduction history of Tibetan ophiolites. Sci. Rep., 8 , 5457.

Bonazzi, P. \& Bindi, L. (2015): Determination of the tegengrenite superstructure: another case of tetrahedral $\mathrm{Mn}^{3+}$ in spinel-type minerals? Mineral. Mag., 79, 425-436.

Bonazzi, P., Chelazzi, L., Bindi, L. (2013): Superstructure, crystal chemistry and cation distribution in filipstadite, a $\mathrm{Sb}^{5+}$-bearing, spinel-related mineral. Am. Mineral., 98, 361-366.

Bosi, F. (2018): On the mineral nomenclatures: the dominantvalency rule, Abstract to XXII meeting of the IMA, Melbourne, Australia, 354.

Bosi, F. \& Andreozzi, G.B. (2017): Chromium influence on Mg-Al intracrystalline exchange in spinels and geothermometric implications. Am. Mineral., 102, 333-340.

Bosi, F., Hålenius, U., Skogby, H. (2009): Crystal chemistry of the magnetite-ulvöspinel series. Am. Mineral., 94, 181-189.

_, _, - (2014): Crystal chemistry of the ulvöspinel-qandilite series. Am. Mineral., 99, 847-851.

Bowles, J.F.W., Vaughan, D.J., Howie, R.A., Zussman, J. (2011): Rock-Forming Minerals. Vol. 5A, Non-silicates: Oxides, Hydroxides and Sulphides, The Geological Society, London.

Bragg, W.H. (1915): The structure of the spinel group of crystals. Philos. Mag., 30, 305-315. 
Buckley, A.N., Skinner, W.M., Harmer, S.L., Pring, A., Fan, L.-J. (2009): Electronic environments in carrollite, $\mathrm{CuCo}_{2} \mathrm{~S}_{4}$, determined by soft X-ray photoelectron and absorption spectroscopy. Geochim. Cosmochim. Acta, 73, 4452-4467.

Charnock, K., Garner, C.D., Pattrick, R.A.D., Vaughan, D.J. (1990): An EXAFS study of thiospinel minerals. Am. Mineral., 75, 247-255.

Ching, W.Y., Mo, S.-D., Tanaka, I., Yoshiya, M. (2001): Prediction of spinel structure and properties of single and double nitrides. Phys. Rev. B, 63, 064102.

Collyer, S., Grimes, N.W., Vaughan, D.J., Longworth, G. (1988): Studies of the crystal structure and crystal chemistry of titanomaghemite. Am. Mineral., 73, 153-160.

Craig, J.R. \& Carpenter, A.B. (1977): Fletcherite, $\mathrm{Cu}(\mathrm{Ni}, \mathrm{Co})_{2} \mathrm{~S}_{4}$, a new thiospinel from the Viburnum Trend (new lead belt). Econ. Geol., 72, 480-486.

Della Giusta, A., Carbonin, S., Ottonello, G. (1996): Temperaturedependent disorder in a natural $\mathrm{Mg}-\mathrm{Al}-\mathrm{Fe}^{2+}-\mathrm{Fe}^{3+}$-spinel. Mineral. Mag., 60, 603-616.

Dunn, P.J., Peacor, D.R., Criddle, A.J., Stanley, C.J. (1988): Filipstadite, a new $\mathrm{Mn}-\mathrm{Fe}^{3+}{ }_{-} \mathrm{Sb}$ derivative of spinel, from Långban, Sweden. Am. Mineral., 73, 413-419.

Garg, G., Bobev, S., Roy, A., Ghose, J., Das, D., Ganguli, A.K. (2001): Single crystal structure and Mössbauer studies of a new cation-deficient thiospinel: $\mathrm{Cu}_{5.47} \mathrm{Fe}_{2.9} \mathrm{Sn}_{13.1} \mathrm{~S}_{32}$. Mater. Res. Bull., 36, 2429-2435.

Goodenough, J.B. (1969): Descriptions of outer $d$ electrons in thiospinels. J. Phys. Chem. Solids, 30, 261-280.

Greaves, C. (1983): A powder neutron diffraction investigation of vacancy ordering and covalence in $\gamma-\mathrm{Fe}_{2} \mathrm{O}_{3}$. J. Solid State Chem., 49, 325-333.

Gross, P.J. \& Jansen, M. (1994): Synthesis and crystal structure of Cu2PtIIPt3IVS8. Z. Anorg. Allg. Chem., 620, 1909-1914.

Hatert, F. \& Burke, E.A.J. (2008): The IMA-CNMNC dominantconstituent rule revisited and extended. Can. Mineral., 46, 717-728.

Hawthorne, F.C. (2002): The use of end-member charge-arrangements in defining new mineral species and heterovalent substitutions in complex minerals. Can. Mineral., 40, 699-710.

Holtstam, D. \& Larsson, A.K. (2000): Tegengrenite, a new, rhombohedral spinel-related $\mathrm{Sb}$ mineral from the Jakobsberg Fe-Mn deposit, Värmland, Sweden. Am. Mineral., 85, 1315-1320.

Jarosch, D. (1987): Crystal structure refinement and reflectance measurements of hausmannite, $\mathrm{Mn}_{3} \mathrm{O}_{4}$. Mineral. Petrol., 37, 15-23.

Jørgensen, J., Mosegaard, L., Thomsen, L.E., Jensen, T.R., Hanson, J.C. (2007): Formation of $\gamma-\mathrm{Fe}_{2} \mathrm{O}_{3}$ nanoparticles and vacancy ordering: An in situ X-ray powder diffraction study. J. Solid State Chem., 180, 180-185.

Jumas, J.C., Philippot, E., Maurin, M. (1979): Structure du rhodostannite synthétique - Locality: synthetic. Acta Crystallogr. B, 35, 2195-2197.

Lenaz, D., Skogby, H., Princivalle, F., Hålenius, U. (2004): Structural changes and valence states in the $\mathrm{MgCr}_{2} \mathrm{O}_{4}-\mathrm{FeCr}_{2} \mathrm{O}_{4}$ solid solution series. Phys. Chem. Miner., 31, 633-642.

Lenaz, D., Skogby, H., Nestola, F., Princivalle, F. (2008): OH incorporation in nearly pure $\mathrm{MgAl}_{2} \mathrm{O}_{4}$ natural and synthetic spinels. Geochim. Cosmochim. Acta, 72, 475-479.

Lenaz, D., O'Driscoll, B., Princivalle, F. (2011): Petrogenesis of the anorthosite-chromitite association: crystal-chemical and petrological insights from the Rum Layered Suite, NW Scotland. Contrib. Mineral. Petrol., 162, 1201-1213.

Lucchesi, S., Bosi, F., Pozzuoli, A. (2010): Geothermometric study of Mg-rich spinels from the Somma-Vesuvius volcanic complex (Naples, Italy). Am. Mineral., 95, 617-621.

Marcano, J.R., Mora, A.E, Odreman, O., Delgado, J.M (1996): Single-crystal structural study of a natural ( $\mathrm{Zn}, \mathrm{Mn})$ ferrite. Mater. Res. Bull., 31, 1587-1592.
Matsubara, S., Kato, A., Nagashima, K. (1979): Iwakiite, $\mathrm{Mn}^{+2}\left(\mathrm{Fe}^{+3}, \mathrm{Mn}^{+3}\right)_{2} \mathrm{O}_{4}$, a new tetragonal spinelloid mineral from the Gozaisho mine, Fukushima Prefecture, Japan. Mineral. J. (Japan), 9, 383-391.

McAndrew, J. (1956): Observations on hydrohetaerolite. Am. Mineral., 41, 268-275.

Meisser, N. \& Perseil, E. A. (1993): Occurrence of woodruffite, (Zn, $\left.\mathrm{Mn}^{+2}\right) \mathrm{Mn}_{4}^{3+} \mathrm{O}_{7} \cdot 1-2 \mathrm{H}_{2} \mathrm{O}$, hetaerolite, $\mathrm{ZnMn}_{2} \mathrm{O}_{4}$, and hydrohetaerolite, $\mathrm{HZnMn}_{2-x} \mathrm{O}_{4}$, of supergene origin in a skarn of Mount Chemin (Valais, Switzerland). Schweiz. Mineral. Petrogr. Mitt., 73, 11-19.

Mills, S.J., Hatert, F., Nickel, E.H., Ferraris, G. (2009): The standardisation of mineral group hierarchies: application to recent nomenclature proposals. Eur. J. Mineral., 21, 1073-1080.

Mitchell, R.H. (1995): Kimberlites, orangeites, and related rocks, New York, Plenum Press.

Müller, U. (2007): Inorganic structural chemistry, John Wiley \& Sons Ltd, Hoboken, United States, 275 p.

Nakatsuka, A., Ueno, H., Nakayama, N., Mizota, T., Maekawa, H. (2004): Single crystal X-ray diffraction study of cation distribution in $\mathrm{MgAl}_{2} \mathrm{O}_{4}-\mathrm{MgFe}_{2} \mathrm{O}_{4}$ spinel solid solution. Phys. Chem. Miner, 31, 278-287.

Nell, J., Wood, B.J., Mason, T.O. (1989): High temperature cation distributions in $\mathrm{Fe}_{3} \mathrm{O}_{4}-\mathrm{MgAl}_{2} \mathrm{O}_{4}-\mathrm{MgFe}_{2} \mathrm{O}_{4}-\mathrm{FeAl}_{2} \mathrm{O}_{4}$ spinels from thermopower and conductivity measurements. Am. Mineral., 74, 339-351.

Nickel, E.H. \& Grice, J.D. (1998): The IMA Commission on New Minerals and Mineral Names: procedures and guidelines on mineral nomenclature. Can. Mineral., 36, 913-926.

Nishikawa, S. (1915): The structure of some crystals of the spinel group. Proc. Math. Phys. Soc. Tokyo, 8, 199-209.

O'Neill, H.St.C. \& Navrotsky, A. (1984): Cation distribution and thermodynamic properties of binary spinel solid solutions. Am. Mineral., 69, 733-753.

O'Neill, H.St.C., Annersten, H., Virgo, D. (1992): The temperature dependence of the cation distribution in magnesioferrite $\left(\mathrm{MgFe}_{2} \mathrm{O}_{4}\right)$ from powder XRD structural refinements and Mössbauer spectroscopy. Am. Mineral., 77, 725-740.

Oktyabrsky, R.A., Shcheka, S.A., Lennikov, A.M., Afanasyeva, T.B. (1992): The first occurrence of qandilite in Russia. Mineral. Mag., 56, 385-389.

Ostwald, J. (1985): Fletcherite and its genesis in the Kalgoorlie area, Western Australia. N. Jb. Mineral. Mon., 1985 (1) $35-44$.

Palache, C. (1928): Mineralogical notes on Franklin and Sterling Hill, New Jersey. Am. Mineral., 13, 297-313.

Papike, J.J., Karner, J.M., Shearer, C.K. (2005): Comparative planetary mineralogy: Valence state partitioning of $\mathrm{Cr}, \mathrm{Fe}, \mathrm{Ti}$, and $\mathrm{V}$ among crystallographic sites in olivine, pyroxene, and spinel from planetary basalts. Am. Mineral., 90, 277-290.

Papike, J.J., Burger, P.V., Bell, A.S., Shearer, C.K., Le, L., Jones, J. (2015): Normal to inverse transition in Martian spinel: understanding the interplay between chromium, vanadium, and iron valence state partitioning through a crystal-chemical lens. Am. Mineral., 100, 2018-2025.

Pattrick, R.A.D., Coker, V.S., Pearce, C.I., Telling, N.D., van der Laan, G. (2008): The oxidation state of copper and cobalt in carrollite, $\mathrm{CuCo}_{2} \mathrm{~S}_{4}$. Can. Mineral., 46, 1317-1322.

Pekov, I.V., Anikin, L.P., Chukanov, N.V., Belakovskiy, D.I., Yapaskurt, V.O., Sidorov, E.G., Britvin, S.N., Zubkova, N.V. (2016): Deltalumite, IMA 2016-027. CNMNC Newsletter No. 32, August 2016, page 919. Mineral. Mag., 80, 915-922.

Plumier, R. \& Lotgering, F.K. (1970): Antiferromagnetic interactions between $\mathrm{Fe}^{3+}$ ions at a large distance in $\mathrm{Fe}_{1 / 2} \mathrm{Cu}_{1 / 2} \mathrm{Rh}_{2} \mathrm{~S}_{4}$. Solid State Commun., 8, 477-480. 
Plumier, R., Sougi, M., Soubeyroux, J.L. (1992): Neutron diffraction reinvestigation of $\mathrm{Fe}_{1 / 2} \mathrm{Cu}_{1 / 2} \mathrm{Rh}_{2} \mathrm{~S}_{4}$. J. Alloys Compd., 178, $51-56$.

Radhakrishnan, N.K. \& Biswas, A.B. (1975): Cation distribution in the tetragonal spinel $\mathrm{MgMn}_{2} \mathrm{O}_{4}$. Z. Kristallogr., 142, 117-120.

Redfern, S.A.T., Harrison, R.J., O’Neill, H.St.C., Wood, D.R.R. (1999): Thermodynamics and kinetics of cation ordering in $\mathrm{MgAl}_{2} \mathrm{O}_{4}$ spinel up to $1600{ }^{\circ} \mathrm{C}$ from in situ neutron diffraction. Am. Mineral., 84, 299-310.

Riedel, E., Karl, R., Rackwitz, R (1981): Mössbauer studies of thiospinels. V. The systems $\mathrm{Cu}_{1-x} \mathrm{Fe}_{x} \mathrm{Me}_{2} \mathrm{~S}_{4}(\mathrm{Me}=\mathrm{Cr}, \mathrm{Rh})$ and $\mathrm{Cu}_{1-x} \mathrm{Fe}_{x} \mathrm{Cr}_{2}\left(\mathrm{~S}_{0.7} \mathrm{Se}_{0.3}\right)_{4}$. J. Solid State Chem., 40, 255-265.

Righter, K., Sutton, S.R., Newville, M., Le, L., Schwandt, C.S., Uchida, H., Lavina, B., Downs, R.T. (2006): An experimental study of the oxidation state of vanadium in spinel and basaltic melt with implication for the origin of planetary basalt. Am. Mineral., 91, 1643-1656.

Rohrer, G.S. (2001): Structure and bonding in crystalline materials. Cambridge University Press, Cambridge, 548 p.

Rudashevsky, N.S., Men'shikov, Yu.P., Mochalov, A.G., Trubkin, N.V., Shumskaya, N.I., Zhdanov, V.V. (1985): Cuprorhodsite $\mathrm{CuRh}_{2} \mathrm{~S}_{4}$ and cuproiridsite $\mathrm{CuIr}_{2} \mathrm{~S}_{4}$ - new natural thiospinels of platinum-group elements. Zap. Vses. Mineral. Obsh., 114 (2), 187-195 (in Russian).

Rudashevsky, N.S., Mochalov, A.G., Men'shikov, Yu.P., Shumskaya, N.I. (1998): Ferrorhodsite $(\mathrm{Fe}, \mathrm{Cu})(\mathrm{Rh}, \mathrm{Pt}, \mathrm{Ir})_{2} \mathrm{~S}_{4}-$ a new mineral. Zap. Vses. Mineral. Obsh., 127 (5), 37-41 (in Russian).

Sassmannshausen, M., Solinas, I., Lutz, H.D. (1996): Crystal structure of dilithium zinc tetrachloride, $\mathrm{Li}_{2} \mathrm{ZnCl}_{4}$ with olivineand spinel-type structure. Z. Kristallogr., 211, 819-820.

Shmakov, A.N., Kryukova, G.N., Tsybulya, S.V., Chuvilin, A.L., Solovyeva, L.P. (1995): Vacancy ordering in gamma- $\mathrm{Fe}_{2} \mathrm{O}_{3}$ : synchrotron $\mathrm{X}$-ray powder diffraction and high-resolution electron microscopy studies. J. Appl. Crystallogr., 28, 141-145.
Springer, G. (1968): Electronprobe analyses of stannite and related tin minerals. Mineral. Mag., 36, 1045-1051.

Steigmann, G.A. (1967): The crystal structures of $\mathrm{ZnAl}_{2} \mathrm{~S}_{4}$. Acta Crystallogr., 23, 142-147.

Vaughan, D.J. \& Craig, J.R. (1978): Mineral chemistry of metal sulfides, Cambridge University Press, UK.

—, - (1985): The crystal chemistry of iron-nickel thiospinels. Am. Mineral., 70, 1036-1043.

Von Philipsborn, H. (1971): Chalcogenide spinels and alternative structures. Z. Kristallogr, 133, 464-472.

Wada, S., Sugita, H., Miyatani, K., Tanaka, T., Nishikawa, T. (2002): Weak antiferromagnetism and superconductivity in pseudo-binary spinel compounds $(\mathrm{Cu}, \mathrm{Co}) \mathrm{Co}_{2} \mathrm{~S}_{4}$ investigated by ${ }^{59} \mathrm{Co}$ and ${ }^{63} \mathrm{Cu}$ magnetic resonance. Condens. J. Phys. Matter, 14, 219-230.

Yang, H., Hubler, D.K., Lavina, B., Downs, R.T., Costin, G (2007): Tyrrellite, $\mathrm{Cu}\left(\mathrm{Co}_{0.68} \mathrm{Ni}_{0.32}\right)_{2} \mathrm{Se}_{4}$, isostructural with spinel. Acta Crystallogr. C, 63, i73-i74.

Yajima, J., Ohta, E., Kanazawa, Y. (1991): Toyohaite, $\mathrm{Ag}_{2} \mathrm{FeSn}_{3} \mathrm{~S}_{8}$, a new mineral. Mineral. J. (Japan), 15, 222-232.

$\mathrm{Yu}, \mathrm{Z}$. (1981): A restudy of malanite and cobalt-malanite (dayingite). Geol. Rev., 27, 55-71 (in Chinese with English abstract).

- (1996): Malanite - A new cupric platinum $\left(\mathrm{Pt}^{3+}\right)$ and iridium $\left(\mathrm{Ir}^{3+}\right)$ sulfide. Acta Geol. Sin., 70, 309-314 (in Chinese with English abstract).

Yu, T.H., Lin, S.J., Chao, P., Fang, C.S., Huang, C.S. (1974): A preliminary study of the platinum group and another associated new one in platinum-bearing intrusions in a region of China. Acta Geol. Sin., 2, 202-218 (in Chinese with English abstract).

Received 11 April 2018

Modified version received 25 June 2018

Accepted 6 July 2018 